\title{
AN ANALYSIS ON UNDERGRADUATE STUDENTS' ABSTRACTS AT ENGLISH EDUCATION DEPARTMENT IN MANADO STATE UNIVERSITY
}

\author{
Andreas Lalogiroth
}

\begin{abstract}
The aim of this research was to find out and identify grammatical errors contained in abstract of undergraduate theses written by students at English Education Department in Manado State University. This research used descriptive method. In the data gathering, this study applied purposive sampling technique. The subject of this research was 50 abstracts of undergraduate theses published only in 2018 and then analyzed by using error analysis technique. Based on the findings, the most frequent error made by the students was omission with 19 errors (37.25\%), addition with 8 errors (15.68\%), archiform with 6 errors (11.76\%), misformation with 11 errors (21.56\%), and the least was misordering with 2 errors $(3.92 \%)$. This shows that there is still need for improvement in grammar teaching and learning for academic writing should be free from grammatical mistakes. From 50 abstracts documented by the researcher, there are only 21 abstract which are grammatically correct, and 29 abstracts contain 51 errors. Since abstract is the published piece for research report by graduated students, there should be more concern in abstract writing, particularly its accuracy in grammar.
\end{abstract}

Keywords: Grammatical error, abstract, undergraduate thesis, English Education Department

\section{INTRODUCTION}

Writing as one of language skills is regarded as a productive activity besides speaking skill. Being a bit different from speaking skills in terms of the demand for the accuracy, writing demands comprehensive ways in the sense of the grammatical construction, the choice of the words and the punctuation use as well as the potential of analytical ability (Maru, Ratu and Dukut, 2018). In writing, language users explore their ideas or thoughts and critical thinking as well. Writing runs the expressive function of language. Writing activity potentially reflects the mastery of other aspects such as vocabulary and grammar in combination. Writing is commonly done in various setting, including academic setting. 
Grammar is meant as the core element of language for language is conceptualized as a system. Good comprehension of grammar determines the accuracy of language mastery. Grammar is seen as fundamental element in writing process. Grammar structures the language itself, in order to make meaning of the utterances clear and understandable. Grammar is positioned as the elaboration constructing words, phrases. Clauses, sentences, paragraph up to discourse. Therefore, in the aim of being skillful in language, a learner needs to master the grammar, so the utterances can be grammatically meaningful.

Grammar is one of very vital components in language. Freeman and Freeman (2004) contributes the definitions of grammar based on its meanings: (1) grammar as a description of syntactic structure; (2) grammar as prescriptions for how to use structures and words; (3) grammar as rhetorically effective use of syntactic structures; (4) grammar as the functional command of sentence structure that enables us to comprehend and produce language. Grammar is not only how utterances can be syntactically correct but also well produced and comprehended.

Writing in academic context actually is not as easy as sounds. One of academic writing instances is abstract. In academic context, abstract is written when a researcher has finished his or her research project. Writing abstract is an obligation for students whenever they carry out their research and then write thesis. Abstract in English is a must to compose for the students no matter what their study fields. Abstract becomes the brief work especially composed for providing primary information for readers about what was done by the research in his or her research. It cannot be denied that mostly readers only read abstract to decide their interest about the research. In other words, they should not read the entire work to understand the research. Abstract also becomes the published piece of research report that can be easily accessed in public setting. English students are expected to be better in composing English abstract compared to students who majoring other fields of study.

Good abstract is also seen from how well the grammar is used. Abstract is used as simple way to understand the overall research project. It is implied that if the abstract is well written that there is good writing accuracy indicated. According to Berkenkotter \& Huckin (1995), there are four reasons that make abstract plays an important role in research articles. First, it provides important information or statements that are easy to be accessed. Second, it functions as the screening device that can help readers to decide whether they will finish reading the whole content. Third, it gives a framework for readers to read the article. Fourth, it provides summaries of primary points of a research article.

Bhatia (1993) explains that the word abstract means, "A description or factual summary of the much longer report, and is meant to give the reader an exact and concise knowledge of the full article." The generic purpose of research article abstract, according to Martín- Martín (2005), is "to provide the summary of the content of the accompanying 
article". Having read abstract, the overall content of a research then is known. That's why abstract should be structurally composed.

Language learning in academic setting is sometimes problematic. Learners tend to make error in all language skills, including writing. According to Brown (2007: 226), an error is a deviation from the adult grammar of native speakers which signifies the inter language capability of the language learners. For language learners, it is very common to make errors during their process of learning a language because their competence of the language is still being improved (Ellis, 1994: 48). In fact, although grammar lessons have been taught long before final semester, grammatical errors are still found. Error analysis is an effective way to evaluate the mastery of language.

English students in English Education Department should be able to compose undergraduate thesis in their final period of study in which abstract should be included. In fact, it is undoubtedly real that students make error in writing English abstract. However, higher expectation is given to them who have passed English grammar lessons in their previous semesters, in comparison to students with different major. It is important to see the quality of English used by English students in their abstracts. From the considerations above, the research is done for the purpose of finding out and identifying grammatical errors contained in abstracts of undergraduate thesis written by students at English Education Department in Manado State University.

\section{THEORETICAL BASES}

\section{a. Grammar's Importance in Academic Writing}

Academic writing cannot be separated from academic lives of students particularly those who majoring English Education. Moreover, academic writing, in comparison with free writing activity seems to be more structured and it is systematically done by writer or researcher. Writing in academic context needs consistency in terms of writing rules and appropriate use of language as well. Eventually, good content of writing and correct use of language leads to successful meaning delivery in combination.

Grammar plays role as foundation in language. Weaver (as cited in Freeman and Freeman, 2004) defines grammar based on its meanings: (1) grammar as a description of syntactic structure; (2) grammar as prescriptions for how to use structures and words; (3) grammar as rhetorically effective use of syntactic structures; (4) grammar as the functional command of sentence structure that enables us to comprehend and produce language. Through good grammar, a writer effectively expresses his or her message. Sentences should be syntactically correct. Being skillful in grammar is considered vital for academic writer. 
This is undoubtedly needed so that good writer can be the output. Statements or opinions are understood from well-structured sentences. On the other hand, ill-formed sentences cause failure in production and misinterpretation in comprehension. In short the impacts of imperfect use of grammar come to both readers and the writer himself or herself.

Purpura (2004) defines grammar as follows:

"Grammar is defined as a systematic way accounting for predicting an ideal speaker's or hearer's knowledge of the language. This is done by a set of rules or principles that can be used to generate all well-formed or grammatical utterances in the language." (6)

\section{b. Abstract}

Abstract is a brief summary of a report or research project and describes primary parts of a full paper of research. In Oxford Advanced Learner's Dictionary, abstract is meant as a short piece of writing containing the main ideas in a document (2010:6). Abstract is required in written research report. Having conducted certain research, the researcher writes abstract. Abstract itself aims at providing main information for readers as brief report that reflect the entire content of the research report. By reading abstract, readers at least understand what was done by the researcher in his or her research. Some people only read abstract in order to decide whether this research is good or not without having to entirely read the full paper. That is why it is important for academic writers to compose good and meaningful abstract.

A good abstract from the case of elements has several parts. According to Weissberg and Buker (1990 : 186), the five elements of abstract are:

\section{Some background information}

2. The principal activity (or purpose) of the study and its scope

3. Some information about methodology used in the study

4. The most important result of the study

5. A statement of conclusion or recommendation

It is found sometimes differences done by the writer in putting those above parts in order. However, a complete abstract ideally contains those elements.

\section{c. Error Analysis}

It is normal for anyone who learns the foreign language for making mistakes and errors because it is different from his/her mother tongue. Littlewood in Wardhana (2002: 2) stated that errors might enrich learners' knowledge about the language they are learning, because when making errors they are actually learning something from them. 
Error Analysis is useful in the purpose of evaluating the language accuracy contained in written work including abstract. According to James (1998: 1), error analysis is the process of concluding the occurrence, nature, reasons and effect of unsuccessful language. This is an effective solution for preventing learners or all language users from inappropriate way of language use. Otherwise, this possibly leads to habit.

According to Dulay, Burt and Krashen (1982: 155), there are four types of errors based on the surface strategy taxonomy: omission, addition, misformation and misordering.

a. Omission

Omission errors are characterized by the absence of items that must be present in a well-formed utterance.

Example:

a) The primary source is the novel entitled Wonder by R. J. Palacio and the secondary sources are taken from some books, articles, dictionaries, and internet data related to the topic.

The utterance should be:

a) The primary source is the novel entitled Wonder by R. J. Palacio and the secondary sources are taken from some books, articles, dictionaries, and internet data that related to the topic.

b. Addition

Addition errors are the opposite of omission errors. They are characterized by the presence of an item which must not be present in a wellformed utterance. Dullay, Burt and Krashen, (1982: 156) as quoted by Haryono (2011: 6) divides addition error into three types, they are as follows:

1. Double Marking

Many addition errors are more accurately described as the failure to delete certain items which are required in some linguistics construction, but not in others.

Example:

a. In order to get the data, the researcher asked the students to write a description about one of their family members (father, mother, brother, or sister). After analyzing and describing the types of errors, the researcher did found there are 162 items of grammatical error occur in students' descriptive writing.

The correct utterance is:

a. In order to get the data, the researcher asked the students to write a description about one of their family members (father, mother, brother, or sister). After analyzing and describing the types of errors, the researcher found there are 162 items of grammatical error occur in students' descriptive writing. 
2. Regularization

Regularization error refers to an error having exceptional items of the given class that do not take a marker's form.

For example:

$\begin{array}{ll}\text { Incorrect } & \text { Correct } \\ \text { Persons } & \text { People (plural from person) } \\ \text { Tooths } & \text { Teeth(plural from child) } \\ \text { Choosed } & \text { Chose (past tense from choose) }\end{array}$

The examples above are regularization errors, in which the regular plural noun and tense markers respectively have been added to items which do not take marker.

3. Simple Addition

Errors of simple addition refer to the addition of one element to the correct utterance.

Example:

a) The teacher does not marks students' essay

b) Students should to be active in classroom

In the utterance a), the sentence should be The teacher does not marks students' essay, and in the utterance b), the sentence Students should to be active in classroom is ill formed because there is no need to add the word to before the word be. So the correct one is Students should to be active in classroom.

c. Misformation

Misformation errors are characterized by the use of the unacceptable forms of the morpheme or structure. While in omission errors the item is not supplied at all, in misformation errors the learner supplies something, although it is incorrect. There are three subtypes of misformation errors, they are as follows:

1. Regularization Errors

Regularization errors are errors in which regular marker are used in place of irregular ones, as in readed for read or mouses for mice.

2. Archiforms

The selection of marker of one member of a class of forms to represent other in the class is a common characteristic of all stages of second language acquisition. The form selected by the learner is called archiforms.

The following examples are dealing with the use of demonstrative adjective this, that, these, and those. 
Example:

That pens This teachers

These board Those board

This type of misformation errors has been called archiform that should be followed by singular forms, while these should be followed by the plural forms, and the correct form of the examples above are as follows:

That pen This teacher

These boards Those boards

3. Alternating Form

As learner's vocabulary and grammar grow, the use of archiform often gives away to the free alternation of various member of class with each other.

a. He gone to the market two days ago

b. You would have took those books.

The sentences above have incorrect verbs gone and took instead of went and taken.

d. Misordering Errors

The incorrect placement of a morpheme or group of morphemes in an utterance characterized misordering error. Misordering errors occur systematically for both first language and second language learners.

Examples:

1) Descriptive statistics is applied to count the mean of the students' score. The research shows that using student tutor technique in teaching reading comprehension of texts descriptive positively effects students' reading comprehension.

The sentence above has ungrammatical use of texts and descriptive. Structurally, the utterance should be:

1) Descriptive statistics is applied to count the mean of the students' score.The research shows that using student tutor technique in teaching reading comprehension of descriptive texts positively effects students' reading comprehension.

\section{METHOD}

The type of the study used in this study is descriptive qualitative research. "Qualitative refers to the meaning, the definition or analogy or model or metaphor characterizing something“(Maanen, 1983:32). Further, Maanen (1983:37) states that qualitative research related with the time, space and the other elements that can be distributed analytically. The processed of qualitative research will form a pattern can be used for long time. The place and things dimension can be summarized. (Maanen, 1983: 37) 
The source of analyzed data in this study through documentation was taken from undergraduate theses that were written by the students of English Education Department, Faculty of Languages and Art in Manado State University who have graduated and whose research report s or articles have been published and also can be accessed. To be exact, the writer took fifty abstract published only 2018. It means that the data are still latest abstracts. In analyzing the data, the researcher did a non-statistical analysis based on the shown data.

The steps in analyzing data in this study are :

1. Documenting abstracts in undergraduate theses published in 2018

2. Reading and checking the error sentences that are present in the undergraduate theses

3. Categorizing the error with theory

4. Calculating each kind of error to find the most frequent and the least error. In counting the frequent errors the writer use the following formula :

$$
\text { PERCENTAGE OF ERROR }(r)=\frac{\operatorname{NUMBER~OF~ERROR~}(\mathrm{x})}{\text { TOTAL OF ERROR }(\mathrm{y})}
$$

\section{FINDINGS AND DISCUSSION}

In total, there are fifty one grammatical errors detected in the abstracts

written. by students at English Education Department. In particular, there are three errors classified as alternating form, six errors grouped as archiform, nineteen errors categorized as omission, eight errors that are in type of addition, eleven errors which are in kind of misformation, and two errors are in category of misordering. Based on the result, misordering error become the least error type done by the students. On the contrary, omission becomes the most frequent error found in students' abstracts

\begin{tabular}{|l|l|l|l|}
\hline \multicolumn{3}{|c|}{ Table 1. Identification of Grammatical Error in English Students' Abstracts } \\
\hline NO & \multicolumn{1}{|c|}{ DATA } & \multicolumn{1}{|c|}{$\begin{array}{c}\text { CATEGORY OF } \\
\text { ERROR }\end{array}$} & \multicolumn{1}{c|}{ CORRECT FORM } \\
\hline 1 & $\begin{array}{l}\text { This study aimed to } \\
\text { describe of the use of Hot } \\
\text { Seat Game }\end{array}$ & $\begin{array}{l}\text { ALTERNATING } \\
\text { FORM }\end{array}$ & $\begin{array}{l}\text { This study aimed at describing the use } \\
\text { of Hot Seat Game }\end{array}$ \\
\hline 2 & $\begin{array}{l}\text { Thus, it could be conclude } \\
\text { that the use of Hot Seat } \\
\text { Game is }\end{array}$ & OMISSION & $\begin{array}{l}\text { Thus, it could be concluded that the use } \\
\text { of Hot Seat Game is }\end{array}$ \\
\hline
\end{tabular}




\begin{tabular}{|c|c|c|c|}
\hline 3 & $\begin{array}{l}\text { This technique can } \\
\text { motivated students to } \\
\text { learn English through act } \\
\text { out words. }\end{array}$ & ADDITION & $\begin{array}{l}\text { This technique can motivate students to } \\
\text { learn English through act out words. }\end{array}$ \\
\hline 4 & $\begin{array}{l}\text { This research aims to find } \\
\text { out the metaphor used in } \\
\text { Bon Jovi's song lyrics, }\end{array}$ & $\begin{array}{l}\text { ALTERNATING } \\
\text { FORM }\end{array}$ & $\begin{array}{l}\text { This research aims at finding out the } \\
\text { metaphor used in Bon Jovi's song } \\
\text { lyrics, }\end{array}$ \\
\hline 5 & $\begin{array}{l}\text { There's no words that } \\
\text { delivered with directly } \\
\text { meaning. }\end{array}$ & ARCHIFORM & $\begin{array}{l}\text { There are no words that delivered with } \\
\text { directly meaning. }\end{array}$ \\
\hline 6 & $\begin{array}{l}\text { The readers be able to } \\
\text { know about semantics, }\end{array}$ & OMISSION & $\begin{array}{l}\text { The readers would be able to know } \\
\text { about semantics, }\end{array}$ \\
\hline 7 & $\begin{array}{l}\text { The aim of this research is } \\
\text { to identify and to describe } \\
\text { the Slang words }\end{array}$ & OMISSION & $\begin{array}{l}\text { The aim of this research are to identify } \\
\text { and to describe the Slang words }\end{array}$ \\
\hline 8 & $\begin{array}{l}\text { writer choose this method } \\
\text { because is compatible } \\
\text { with the research }\end{array}$ & MISFORMATION & $\begin{array}{l}\text { writer chose this method because is } \\
\text { compatible with the research }\end{array}$ \\
\hline 9 & $\begin{array}{l}\text { After the writer analyzing } \\
\text { the data, the writer found } \\
\text { at how the slang words }\end{array}$ & ARCHIFORM & $\begin{array}{l}\text { After the writer analyzing the data, the } \\
\text { writer found out how the slang words }\end{array}$ \\
\hline 10 & $\begin{array}{l}\text { Thus, as showed from the } \\
\text { mean, can be concluded } \\
\text { that dictionary does not } \\
\text { significantly influence the } \\
\text { effectiveness in English } \\
\text { learning }\end{array}$ & OMISSION & $\begin{array}{l}\text { Thus, as showed from the mean, it can } \\
\text { be concluded that dictionary does not } \\
\text { significantly influence the effectiveness } \\
\text { in English learning }\end{array}$ \\
\hline 11 & $\begin{array}{l}\text { Based on this claim, this } \\
\text { research question: Does } \\
\text { students'vocabulary } \\
\text { knowledge significantly } \\
\text { affect reading } \\
\text { comprehension? }\end{array}$ & OMISSION & $\begin{array}{l}\text { Based on this claim, this is the research } \\
\text { question: Does students' vocabulary } \\
\text { knowledge significantly affect reading } \\
\text { comprehension? }\end{array}$ \\
\hline 12 & $\begin{array}{l}\text { The result show that, } \\
\text { acronyms found in online } \\
\text { game Counter Strike }\end{array}$ & MISFORMATION & $\begin{array}{l}\text { The result shows that, acronyms found } \\
\text { in online game Counter Strike }\end{array}$ \\
\hline
\end{tabular}




\begin{tabular}{|c|c|c|c|}
\hline 13 & $\begin{array}{l}\text { Adventure in literary } \\
\text { works are inspired and } \\
\text { some of them are based on } \\
\text { a true story. }\end{array}$ & ARCHIFORM & $\begin{array}{l}\text { Adventure in literary works is inspired } \\
\text { and some of them are based on a true } \\
\text { story. }\end{array}$ \\
\hline 14 & $\begin{array}{l}\text { In real life, adventure } \\
\text { are the life itself. We are } \\
\text { often struggle to deal } \\
\text { with our everyday life } \\
\text { and the challenges are } \\
\text { always there, they are the } \\
\text { obstacle and the efforts we } \\
\text { take and made during the } \\
\text { adventure. }\end{array}$ & MISFORMATION & $\begin{array}{l}\text { In real life, adventure is the life itself. } \\
\text { We often struggle to deal with our } \\
\text { everyday life and the challenges are } \\
\text { always there, they are the obstacle and } \\
\text { the efforts we take and make during the } \\
\text { adventure. }\end{array}$ \\
\hline 15 & $\begin{array}{l}\text { The result of this research } \\
\text { was Alice has become } \\
\text { a confident girl that has } \\
\text { gained skills that she can } \\
\text { adapt.... }\end{array}$ & MISFORMATION & $\begin{array}{l}\text { The result of this research is that Alice } \\
\text { has become a confident girl that has } \\
\text { gained skills that she can adapt..... }\end{array}$ \\
\hline 16 & $\begin{array}{l}\text { The adventure formula } \\
\text { main focus on the central } \\
\text { fantasy of the character or } \\
\text { the hero, }\end{array}$ & MISFORMATION & $\begin{array}{l}\text { The adventure formula mainly focuses } \\
\text { on the central fantasy of the character } \\
\text { or the hero, }\end{array}$ \\
\hline 17 & $\begin{array}{l}\text { She has a big desire in her } \\
\text { life to be fulfill it she does } \\
\text { many ways. }\end{array}$ & OMISSION & $\begin{array}{l}\text { She has a big desire in her life to be } \\
\text { fulfilled it she does many ways. }\end{array}$ \\
\hline 18 & $\begin{array}{l}\text { Her struggle bring her to } \\
\text { become a great woman in } \\
\text { the world. }\end{array}$ & & $\begin{array}{l}\text { Her struggle brings her to become a } \\
\text { great woman in the world. }\end{array}$ \\
\hline 19 & $\begin{array}{l}\text { In analyzing the data, the } \\
\text { researcher himself read } \\
\text { and understands the play. }\end{array}$ & ARCHIFORM & $\begin{array}{l}\text { In analyzing the data, the researcher } \\
\text { himself reads and understands the play. }\end{array}$ \\
\hline 20 & One of the aspect is slang. & OMISSION & One of the aspects is slang. \\
\hline 21 & $\begin{array}{l}\text { The purposes of this study, } \\
\text { as pointed out earlier, } \\
\text { are to describe errors in } \\
\text { writing committed by first } \\
\text { grade students of SMA } \\
\text { Kristen Sonder. }\end{array}$ & MISFORMATION & $\begin{array}{l}\text { The purpose of this study, as pointed } \\
\text { out earlier, is to describe errors in } \\
\text { writing committed by first grade } \\
\text { students of SMA Kristen Sonder. }\end{array}$ \\
\hline
\end{tabular}






\begin{tabular}{|c|c|c|c|}
\hline 22 & $\begin{array}{l}\text { Based on the result above, } \\
\text { English teachers are } \\
\text { expected to not to focus } \\
\text { only on developing the } \\
\text { four language skills }\end{array}$ & ADDITION & $\begin{array}{l}\text { Based on the result above, English } \\
\text { teachers are expected not to focus only } \\
\text { on developing the four language skills }\end{array}$ \\
\hline 23 & $\begin{array}{l}\text { This study is intends } \\
\text { to find the effect of the } \\
\text { use of "student tutor" } \\
\text { in English language } \\
\text { teaching to students" } \\
\text { reading comprehension of } \\
\text { descriptive texts. }\end{array}$ & ADDITION & $\begin{array}{l}\text { This study intends to find the effect of } \\
\text { the use of "student tutor" in English } \\
\text { language teaching to students' reading } \\
\text { comprehension of descriptive texts. }\end{array}$ \\
\hline 24 & $\begin{array}{l}\text { The subjects of this } \\
\text { research consist of } 25 \\
\text { students of the first year } \\
\text { class }\end{array}$ & OMISSION & $\begin{array}{l}\text { The subjects of this research consists of } \\
25 \text { students of the first year class }\end{array}$ \\
\hline 25 & $\begin{array}{l}\text { Meanwhile, in purpose to } \\
\text { analyze the dramatic irony } \\
\text { and its uncovering, the } \\
\text { writer used third-person } \\
\text { objective approach or } \\
\text { dramatic point of view. }\end{array}$ & OMISSION & $\begin{array}{l}\text { Meanwhile, in the purpose to analyze } \\
\text { the dramatic irony and its uncovering, } \\
\text { the writer used third-person objective } \\
\text { approach or dramatic point of view. }\end{array}$ \\
\hline 26 & $\begin{array}{l}\text { After analyzing the drama, } \\
\text { the writer find out that } \\
\text { people could sometimes } \\
\text { deal with facts which are } \\
\text { not as what they know. }\end{array}$ & OMISSION & $\begin{array}{l}\text { After analyzing the drama, the writer } \\
\text { finds out that people could sometimes } \\
\text { deal with facts which are not as what } \\
\text { they know. }\end{array}$ \\
\hline 27 & $\begin{array}{l}\text { Based on the results of } \\
\text { research and discussion } \\
\text { of the writer can know the } \\
\text { development character of } \\
\text { the main character. }\end{array}$ & MISORDERING & $\begin{array}{l}\text { Based on the results of research and } \\
\text { discussion of the writer can know the } \\
\text { character development of the main } \\
\text { character. }\end{array}$ \\
\hline 28 & $\begin{array}{l}\text { The Hidden Oracle who } \\
\text { has the power but abuse } \\
\text { his power to destroy } \\
\text { the lives of others and } \\
\text { only prioritize his own } \\
\text { interests. }\end{array}$ & OMISSION & $\begin{array}{l}\text { The Hidden Oracle who has the power } \\
\text { but abuses his power to destroy the } \\
\text { lives of others and only prioritizes his } \\
\text { own interests. }\end{array}$ \\
\hline
\end{tabular}




\begin{tabular}{|c|c|c|c|}
\hline 29 & $\begin{array}{l}\text { The results of this study } \\
\text { show that the main } \\
\text { character has changed } \\
\text { from a proud and selfish } \\
\text { person until his trying } \\
\text { to changed into a better } \\
\text { person }\end{array}$ & ADDITION & $\begin{array}{l}\text { The results of this study show that the } \\
\text { main character has changed from a } \\
\text { proud and selfish person until his trying } \\
\text { to change into a better person }\end{array}$ \\
\hline 30 & $\begin{array}{l}\text { The writer choses this } \\
\text { topic because it is } \\
\text { portrayed human life how } \\
\text { we face our fear and how } \\
\text { to conquer our own fear } \\
\text { and not destroy by it. }\end{array}$ & ADDITION & $\begin{array}{l}\text { The writer chose this topic because it is } \\
\text { portrayed human life how we face our } \\
\text { fear and how to conquer our own fear } \\
\text { and not being destroyed by it. }\end{array}$ \\
\hline 31 & $\begin{array}{l}\text { In conducting this } \\
\text { research, the data will be } \\
\text { taken from the the novel }\end{array}$ & MISFORMATION & $\begin{array}{l}\text { In conducting this research, the data } \\
\text { were taken from the novel }\end{array}$ \\
\hline 32 & $\begin{array}{l}\text { Through the story the } \\
\text { writer sees the situation } \\
\text { and condition of Dorothy } \\
\text { how she make decision } \\
\text { and doing something to } \\
\text { help others, Dorothy do a } \\
\text { dangerous thing and face } \\
\text { the frightening condition } \\
\text { and become a very brave } \\
\text { little girl. }\end{array}$ & MISFORMATION & $\begin{array}{l}\text { Through the story the writer sees the } \\
\text { situation and condition of Dorothy how } \\
\text { she made decision and doing something } \\
\text { to help others, Dorothy did a dangerous } \\
\text { thing and faced the frightening } \\
\text { condition and become a very brave } \\
\text { little girl. }\end{array}$ \\
\hline 33 & $\begin{array}{l}\text { Literary works has fully } \\
\text { meaning about life. }\end{array}$ & MISFORMATION & $\begin{array}{l}\text { Literary works have fully meaning } \\
\text { about life. }\end{array}$ \\
\hline 34 & $\begin{array}{l}\text { This study aims to find out } \\
\text { the character development } \\
\text { of the main character }\end{array}$ & $\begin{array}{l}\text { ALTERNATING } \\
\text { FORM }\end{array}$ & $\begin{array}{l}\text { This study aims at finding out the } \\
\text { character development of the main } \\
\text { character }\end{array}$ \\
\hline 35 & $\begin{array}{l}\text { This research is } \\
\text { categorized qualitative } \\
\text { research such the data } \\
\text { gestured are in the form } \\
\text { of words the number. } \\
\text { The literary theory used } \\
\text { in analyzing the data in } \\
\text { objective approach. }\end{array}$ & MISFORMATION & $\begin{array}{l}\text { This research is categorized qualitative } \\
\text { research such the data gestured are in } \\
\text { the form of words rather than number. } \\
\text { The literary theory used in analyzing } \\
\text { the data is objective approach. }\end{array}$ \\
\hline
\end{tabular}




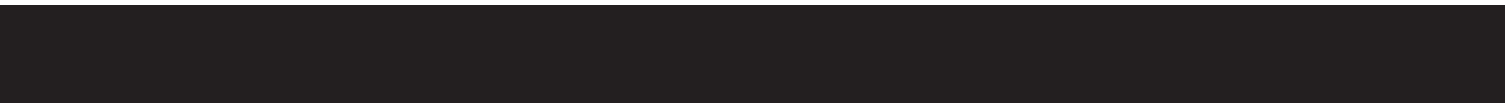

\begin{tabular}{|c|c|c|c|}
\hline 36 & $\begin{array}{l}\text { At first, Hazel Grace was } \\
\text { a girl that loved to be } \\
\text { alone, wasting her time at } \\
\text { home, reading books and } \\
\text { watching tv. Than become } \\
\text { a girl that wants to share } \\
\text { with others and having } \\
\text { friends. }\end{array}$ & OMISSION & $\begin{array}{l}\text { At first, Hazel Grace was a girl that } \\
\text { loved to be alone, wasting her time at } \\
\text { home, reading books and watching TV, } \\
\text { than becoming a girl that wants to share } \\
\text { with others and having friends. }\end{array}$ \\
\hline 37 & $\begin{array}{l}\text { Due to the data analysis, } \\
\text { the writer employ } \\
\text { objective approach. }\end{array}$ & OMISSION & $\begin{array}{l}\text { Due to the data analysis, the writer } \\
\text { employs objective approach. }\end{array}$ \\
\hline 38 & $\begin{array}{l}\text { Beginning introductions } \\
\text { starting from dog Travis } \\
\text { who often go to gabby } \\
\text { house, which makes } \\
\text { Gabby angry. }\end{array}$ & OMISSION & $\begin{array}{l}\text { Beginning introductions starting from } \\
\text { dog of Travis who often go to gabby } \\
\text { house, which makes Gabby angry. }\end{array}$ \\
\hline 39 & $\begin{array}{l}\text { This research also shows } \\
\text { causes and effects of } \\
\text { courage. }\end{array}$ & OMISSION & $\begin{array}{l}\text { This research also shows the causes and } \\
\text { effects of courage. }\end{array}$ \\
\hline 40 & $\begin{array}{l}\text { The data are collected } \\
\text { in two kind of sources, } \\
\text { first is primary source, } \\
\text { that is the novel itself, } \\
\text { Tower of the Five Orders. } \\
\text { Secondary source are } \\
\text { some books, internet } \\
\text { references, and other } \\
\text { relevant references that } \\
\text { used to support the } \\
\text { analysis. }\end{array}$ & OMISSION & $\begin{array}{l}\text { The data are collected in two kinds of } \\
\text { sources, first is primary source, that } \\
\text { is the novel itself, Tower of the Five } \\
\text { Orders. Secondary sources are some } \\
\text { books, internet references, and other } \\
\text { relevant references that used to support } \\
\text { the analysis. }\end{array}$ \\
\hline 41 & $\begin{array}{l}\text { The result of this research } \\
\text { indicate students have } \\
\text { limited comprehension } \\
\text { before }\end{array}$ & OMISSION & $\begin{array}{l}\text { The result of this research indicates } \\
\text { students have limited comprehension } \\
\text { before }\end{array}$ \\
\hline
\end{tabular}




\begin{tabular}{|c|c|c|c|}
\hline 42 & $\begin{array}{l}\text { in this research, } \\
\text { developing students } \\
\text { reading skills using } \\
\text { "up against the wall } \\
\text { technique" has increase } \\
\text { students reading skills. }\end{array}$ & OMISSION & $\begin{array}{l}\text { in this research, developing students } \\
\text { reading skills using "up against the } \\
\text { wall technique" has increased students } \\
\text { reading skills. }\end{array}$ \\
\hline 43 & $\begin{array}{l}\text { Then the impact of } \\
\text { discrimination in social } \\
\text { relation makes the mulatto } \\
\text { being strong and being } \\
\text { motivated to reveal his } \\
\text { identity. }\end{array}$ & ADDITION & $\begin{array}{l}\text { Then the impact of discrimination in } \\
\text { social relation makes the mulatto strong } \\
\text { and motivated to reveal his identity. }\end{array}$ \\
\hline 44 & $\begin{array}{l}\text { This research in } \\
\text { qualitative is used } \\
\text { objective approach in } \\
\text { analyzing the data. }\end{array}$ & ADDITION & $\begin{array}{l}\text { This qualitative research used objective } \\
\text { approach in analyzing the data. }\end{array}$ \\
\hline 45 & $\begin{array}{l}\text { To analyze the data the } \\
\text { writer use objective } \\
\text { approach is applicable } \\
\text { to answer the research } \\
\text { question. }\end{array}$ & OMISSION & $\begin{array}{l}\text { To analyze the data the writer used } \\
\text { objective approach is applicable to } \\
\text { answer the research question. }\end{array}$ \\
\hline 46 & $\begin{array}{l}\text { The purpose of this } \\
\text { research is to have a } \\
\text { description of errors made } \\
\text { by the students in writing } \\
\text { recount text and to reduce } \\
\text { those error. }\end{array}$ & MISFORMATION & $\begin{array}{l}\text { The purposes of this research are to } \\
\text { have a description of errors made by } \\
\text { the students in writing recount text and } \\
\text { to reduce those errors. }\end{array}$ \\
\hline 47 & $\begin{array}{l}\text { John's father suffered } \\
\text { Asperger Syndrome that } \\
\text { make him look different } \\
\text { from other people }\end{array}$ & MISFORMATION & $\begin{array}{l}\text { John's father suffered Asperger } \\
\text { Syndrome that makes him look } \\
\text { different from other people }\end{array}$ \\
\hline 48 & $\begin{array}{l}\text { Guided writing technique } \\
\text { is a technique to helps the } \\
\text { students to improve their } \\
\text { writing performance }\end{array}$ & ADDITION & $\begin{array}{l}\text { Guided writing technique is a technique } \\
\text { to help the students to improve their } \\
\text { writing performance }\end{array}$ \\
\hline 49 & $\begin{array}{l}\text { The sample of this } \\
\text { research was eight grade } \\
\text { which consists of } 23 \\
\text { students. }\end{array}$ & ARCHIFORM & $\begin{array}{l}\text { The sample of this research was Eighth } \\
\text { grade which consists of } 23 \text { students. }\end{array}$ \\
\hline
\end{tabular}




\begin{tabular}{|l|l|l|l|}
\hline 50 & $\begin{array}{l}\text { The aim of this research } \\
\text { were analyzed with find } \\
\text { out the effectiveness of } \\
\text { using picture to increase } \\
\text { students vocabulary } \\
\text { mastery. The researcher } \\
\text { chosen one class } \\
\text { consisting of twenty-three } \\
\text { students of seventh grade } \\
\text { of SMP Negeri 1 Paleleh } \\
\text { as the subject. }\end{array}$ & $\begin{array}{l}\text { The aim of this research is finding } \\
\text { out the effectiveness of using picture } \\
\text { to increase students' vocabulary } \\
\text { mastery. The researcher chose one class } \\
\text { consisting of twenty-three students of } \\
\text { seventh grade of SMP Negeri 1 Paleleh } \\
\text { as the subject. }\end{array}$ \\
\hline 51 & $\begin{array}{l}\text { The objective approach } \\
\text { were applied to analyze } \\
\text { the data gathered. }\end{array}$ & ARCHIFORM & $\begin{array}{l}\text { The objective approach was applied to } \\
\text { analyze the data gathered. }\end{array}$ \\
\hline
\end{tabular}

The researcher then calculated the percentage of error occurred in the abstracts written by English students, as presented in the table below:

\begin{tabular}{|l|l|l|l|}
\hline \multicolumn{3}{|c|}{ Table 2. Percentage of Grammatical Error contained in English Students 'Abstracts } \\
\hline NO & \multicolumn{1}{|c|}{ TYPES OF ERROR } & NUMBER OF ERROR & \multicolumn{1}{c|}{ PERCENTAGE (\%) } \\
\hline 1 & ALTERNATING FORM & 3 & 5.88 \\
\hline 2 & ADDITION & 8 & 15.68 \\
\hline 3 & OMISSION & 19 & 37.25 \\
\hline 4 & MISORDERING & 2 & 3.92 \\
\hline 5 & ARCHIFORM & 6 & 11.76 \\
\hline 6 & MISFORMATION & 11 & 21.56 \\
\hline
\end{tabular}

\section{Conclusion}

Based on the findings, it can be concluded that English students whose research got published in 2018 made omission errors, addition errors, archiforms errors, misordering errors, misformation errors, and alternating form errors in writing abstract of their undergraduate thesis .

In detail, it can be concluded that:

1. English graduated students whose abstracts got published in 2018 at Manado State University made 51 grammatical errors. The most frequent error made by English students in their abstracts of undergraduate thesis is omission and the least error made is misordering

2. English graduated students whose abstracts got published in 2018 at Manado State 
University made alternating forms errors in writing abstract of undergraduate thesis. It is proven by the fact that there were $3(5.88 \%)$ errors contained

3. English students graduated whose abstracts got published in 2018 at Manado State University made addition errors in writing abstract of undergraduate thesis. The evidence is that there were $8(15.68 \%)$ errors.

4. English students graduated whose abstracts got published in 2018 at Manado State University made omission errors in writing abstract of undergraduate thesis. The evidence is the fact that there were $19(37.25 \%)$ errors.

5. English students graduated whose abstracts got published in 2018 at Manado State University made misordering errors in writing abstract of undergraduate thesis. The evidence is the fact that there were $2(3.92 \%)$ errors.

6. English students graduated whose abstracts got published in 2018 at Manado State University made archiform errors in writing abstract of undergraduate thesis. The evidence is the fact that there were $6(11.76 \%)$ errors.

7. English students graduated whose abstracts got published in 2018 at Manado State University made addition errors in writing abstract of undergraduate thesis. The evidence is the fact that there were $11(21.56 \%)$ errors.

\section{Suggestion}

The researcher gives some suggestions dealing with abstract writing in English, as follow:

1. The lecturer

a. The lecturer should give more concern to grammar teaching especially in writing and research class

b. The lecturer needs to guide students as advisor and check the writing accuracy of their research report including abstract

2. The university

a. To adapt the format of international journal in writing abstract to facilitate publishing the journal internationally.

b. To hold training in writing abstract of theses and dissertations.

3. The students

a. Students should be aware that research report including abstract is published work that should be free from ungrammatical sentences

b. The students should be more skillful in grammar comprehension

c. The students need to master the English structure and understand how to apply it in academic writing

d. Students should be more focusing also in writing practice 
e. Students should be aware in error analysis as a good way of learning grammar especially dealing with writing practice

4. The researcher

The researcher himself realized that this work is not perfect at all, so the researcher expect many suggestions and criticism for the perfection of this writing. Hopefully this writing will be beneficial in contributing some insights especially concerning with grammar and academic writing.

\section{Reference}

Berkenkotter, C., \& Huckin, T. N. (1995). Genre knowledge in disciplinary communication: Cognition/culture/ power. New Jersey: Lawrence Erlbaum Associates.

Bhatia, V. K. (1993). Analysing genre: Language use in professional settings. London: Longman.

Brown, H. Douglas. (2007). Principles of Language Learning ang Teaching. Britain: Pearson Longman

Ellis, R. (1994). The Study of Second Language Acquisition. Oxford: Oxford University Press.

Freeman, David E. and Yvonne Freeman. (2004). Essential Linguistics: What You Need to Know to Teach. Portsmouth: Heinemann.

Hornby, A. S. (2010). Oxford Advanced Learner's Dictionary. Oxford: Oxford University Press

James, C. (1998). Errors in Language Learning And Use : Exploring Error Analysis. London and New York: Longman.

Martín-Martín, P. (2005). The rhetoric of the abstract in English and Spanish scientific discourse: A cross-cultural genre-analytic approach (Vol. 21). Bern: Peter Lang.

Maru, Mister Gidion; Ratu, Donal Matheos; Dukut, Ekawati Marhaenny (2018). The Use of the T-Ex Approach in Indonesian EFL Essay Writing: Feedbacks and Knowledge Exploration. IJET Vol 7, No 3.25 (2018), page 386-390

Weissberg, Robert and Suzanne Buker. (1990). Writing Up Research. Englewood Cliffs, NJ: Prentice-Hall 